PF 2019 (LXXIV): 257-265

\title{
L'UBOR KRÁLIK
}

Jazykovedný ústav Ludovíta Štúra Slovenskej akadémie vied

Panská 26, SK-81101 Bratislava 1

tel. +421254431761, +421254431762

e-mail: lubor.kralik@juls.savba.sk

\section{SÚVISÍ SLK. KÁNTRIŤ S POL'. DIAL. KĘTRZYĆ, KĘTRAĆ?*}

KLÚČOVÉ SLOVÁ: slovanské jazyky, slovenský jazyk, polský jazyk, etymológia, sémantika 'zabíjat', ničit'.

SŁOWA KLUCZOWE: języki słowiańskie, język słowacki, język polski, etymologia, semantyka 'zabijać, niszczyc'.

KEYWORDS: Slavic languages, Slovak language, Polish language, etymology, semantics 'kill, destroy'.

\section{IS SLOVAK KÁNTRIŤ RELATED ETYMOLOGICALLY TO POLISH DIAL. KĘTRZYĆ, KĘTRAĆ?}

\begin{abstract}
Slovak kántrit' 'kill, exterminate; ravage, devastate, destroy; cause spiritual suffering' (first attested in A. Bernolák) has no convincing etymology. V. Machek and F. Sławski compared this word to Polish dial. kętrać 'do something in an indecent, immoral way', kętrzyć 'commit adultery' (perhaps related to Kashubian kator 'toad'; from German kunter, kunder 'monster'?). - In the author's opinion, kántrit' is a denominative of Slovak kántry plt, older kántor sg '(in the Roman Catholic church) three days at the beginning of the seasons ordered as days of fast, prayers and repentance, Ember days' (attested since the 17th century) < Latin quattuor (tempora) 'four seasons'. Originally, kántrit' was probably an intransitive verb (*'observe the Ember fast') from which the

* Príspevok vznikol s podporou Vedeckej grantovej agentúry Ministerstva školstva, vedy, výskumu a športu Slovenskej republiky a Slovenskej akadémie vied (VEGA; projekt č. 2/0136/16). Použité skratky jazykov a dialektov: bavor. - bavorský, čes. - český, chorv. - chorvátsky, lat. - latinský, lit. - litovský, mad'. - madarský, nem. - nemecký, pol. - pol'ský, rak. - rakúsky, rus. - ruský, slk./slc. - slovenský, sln. - slovinský, srb. - srbský, sthnem. - starohornonemecký, strfr. - stredofrancúzsky.
\end{abstract}


reflexive kántrit' sa was derived (literally ' "ember» oneself = to afflict, torture, destroy oneself [with \{Ember\} fasting, i. e. with hunger]'); finally, its transitive correlate kántrit' 'destroy, kill, ravage (somebody/something), etc.' also came into existence. Therefore, as a word created in Slovak, kántrit should be separated etymologically from the abovementioned Polish lexemes; at the same time, the assumption that Polish dial. skantrzyć 'kill, strangle' was borrowed from Slovak perf. s-kántrit' (F. Sławski) may be validated.

Slovník súčasného slovenského jazyka (SSSJ II 523) charakterizuje sloveso kántrit' ako expresívum a uvádza preň tri významy: 1. '(čo, koho) (cielene) spôsobovat' smrt', zánik, usmrcovat', zabíjat', hubit' (porov. v slovníku uvedené exemplifikácie kántrit’ myši, obyvatelov kántria choroby a i.), 2. '(čo) spôsobovat' velkú škodu, skazu, pustošit', ničit' (kántrit životné prostredie a i.), 3. '(koho, čo) spôsobovat duševné utrpenie, vyčerpávat" (kántri ho neistota a i.). V citovanom slovníku (op. cit. 524) nachádzame aj reflexívum kántrit' sa expr. 'spôsobovat' si (cielene) navzájom smrt', zánik, usmrcovat’ sa, zabíjat sa, hubit sa' (prečo sa ludia vo vojnách tak kántria).

Ide o výraz, ktorý je $\mathrm{v}$ slovenčine písomne doložený relatívne neskoro. Historický slovník slovenského jazyka (HSSJ) toto sloveso neobsahuje, nachádzame ho až u Antona Bernoláka (II 380: kantrit' - s krátkym a v koreni - 'kwárit', tam i trpné príčastie kantrení 'kwárení a slovesné podstatné meno Kantreňí 'Kwáreňí'). Početné doklady na slovo kántrit'sa vyskytujú aj v tvorbe slovenských autorov pôsobiacich v 19. stor., ako sú napr. Karol A. Modrányi, Bohuslav Nosák-Nezabudov, Jonáš Záborský či Ondrej Seberini ${ }^{1}$; nie je nezaujímavé, že toto sloveso sa objavuje aj v textoch slovenských rozprávok, ktoré zozbieral P. Dobšinský - na základe toho možno usudzovat, že bolo i súčastou ludového jazyka².

V prospech takéhoto predpokladu svedčí nepochybne aj skutočnost', že heslo kántrit' expr. 'ničit, nivočit', zabíjat' nechýba ani v Slovníku slovenských nárečí (SSN I, 745), ktorý zároveň upozorňuje na celoslovenské územné rozšírenie tejto lexémy (porov. použitie kvalifikátora „csl“ [celoslovenský] v záhlaví príslušnej heslovej state $)^{3}$.

1 Príslušné doklady možno získat pomocou vyhladávacieho rozhrania na stránke digitalizačného projektu Zlatý fond denníka SME, kde sú volne dostupné texty uvedených autorov.

2 K výskytu slova u novších autorov porov. - okrem stránky projektu Zlatý fond denníka SME - i SSJ I 672, SSSJ loco cit.

3 Deriváty od slovesa kántrit' (dokonavé prefixálne odvodeniny do-, na-, po-, s-, vykántrit a i.) a ich podrobná filologická dokumentácia by sa mohli stat predmetom samostatnej štúdie; sémanticky sa väčšinou zhodujú s fundujúcim výrazom ( $\mathrm{k}$ sémanticky disparátnemu skántrit’ vo význame 'pozberat' [obilie] z pola' porov. nižšie) a z chronologického hladiska neumožňujú prehíbit jeho datovanie, preto sa im vzhladom na rozsah príspevku podrobnejšie nevenujeme. - Na tomto mieste upozorníme aspoň na dial. kántrnica expr. 'márnotratná žena' (SSN I 745: Klenovec, okres Rimavská Sobota), akiste nadväzujúce na kántrit 'ničit' v kontextoch typu skántrit' celý majetok 
2. Pokial ide o etymológiu slova kántrit', zdá sa, že prvú informáciu etymologického charakteru nachádzame u Miroslava Kálala (1923: 229), ktorý pri heslovom výraze kantrit' (s krátkym a) 'hubiti, pustošiti, mrhati' použil kvalifikátor „mad."“, čo znamená, že tu predpokladal prevzatie madarského pôvodu; Luciano Rocchi (1999-2010) však toto slovo neuvádza.

Výrazu kántrit venoval samostatné heslo V. Machek v 1. vydaní svojho etymologického slovníka: „kántrit slc.: hubiti, pustošiti. Pd. [pol.' dial. - L. K.] kãtrac = kętrzyć hloupě dělati, skantrzyć zabíti a j. Původ nejasný“ (Machek 1957: 191)4. Z citovanej formulácie zároveň vyplýva, že autor pre tento výraz nepredkladá dalšie inoslovanské paralely.

O slk. kántrit' sa zmieňuje aj F. Sławski (SEJP II 129-130 s. v. kętrzyć), ktorý uvádza toto sloveso ako možnú paralelu pre pol. dial. kętrzyć 'cudzołożyć', kętrać 'sprośnie, wszetecznie czynić', pričom zároveň vyslovuje predpoklad, že dokonavé slk. skántrit' mohlo byt prevzaté do polských nárečí („stąd chyba pożyczone nasze znane na Podhalu i w Beskidach skantrzyć 'zabić, zadławić'“). F. Sławski zároveň upozorňuje, že uvedené polské dialektizmy sú doložené len z kašubskej oblasti („w innych dialektach nie spotykane; w stpol. nie zaświadczone“); azda i preto odmieta predpoklad A. Brücknera o genetickej súvislosti polských výrazov s lit. kęsti, kenčiù 'trpiet”', pričom za pravdepodobnejší („,bardziej przekonująco") považuje názor J. Karłowicza, že citované pol’ské nárečové slovesá súvisia s kašubským kątor 'ropucha', vysvetlovaným ako prevzatie zo staršieho nem. kunter, kunder 'obluda, príšera, netvor'6.

3. Nadväzujúc na úvahy F. Sławského, možno si položit otázku, či by sa o etymologickom východisku v podobe už zmieneného nem. kunter, kunder nedalo uvažovat aj v prípade slk. kántrit'. Zdá sa, že zo sémantického hladiska nemusí byt takáto interpretácia (predpokladajúca asociáciu 'obluda, netvor' 'zabíjat', hubit', ničit') celkom nepredstavitelná7, problematickejší je podla nášho názoru formálny aspekt naznačeného výkladu.

(KSSJ 668 s. v. skántrit'). O dial. kántrovnica 'vyšitá stužka, ktorú si dievky dávali pod hlavnicu, aby vo sne videli svojho budúceho manžela' porov. nižšie (pozn. č. 16).

4 V 2. vydaní Machkovho slovníka (Machek 1968) už takéto heslo nenachádzame, z čoho možno usudzovat, že i sloveso kántrit je „výraz, který žije jedině na Slovensku a nemá v českých zemích obdoby nebo odvozeniny“ (op. cit. 7), a preto príslušná heslová stat nebola zaradená do 2. vydania Machkovho diela, koncipovaného už len ako etymologický slovník češtiny. - Porov. i heslá kantrit’, skántrit’ u Fr. Št. Kotta (Kott online s. vv.), obsahujúce kvalifikátor „Slov.“, ktorým sa signalizuje výskyt uvedených slov na Slovensku.

${ }^{5} \mathrm{~K}$ etymologickej problematike litovského výrazu porov. novšie LKEŽDB s. v. kęsti, kenčiu.

6 O kašubskom lexikálnom materiáli porov. novšie SEK III 36 (s. v. kątrac są), 83-84 (s. v. kegtor).

7 Porov. i použitie nem. kunter vo vztahu k rôznym škodlivým zvieratám („auch noch von schädlichem gethier" - DWB loco cit., význam č. 2.d.ß.). 
Bolo by azda možné predpokladat', že slovenčina prevzala nemecký výraz $\mathrm{v}$ jeho variantnej forme konter (porov. DWB online s. v. kunter, kunder: „, nebenform konter"); takéto slk. *konter 'obluda ap.' sa mohlo stat slovotvorným východiskom pre vznik odvodeniny ${ }^{*}$ kontrit' 'správat' sa ako obluda; zabíjat', ničit ap.' s frekventatívom, resp. iteratívom * kántrat 'zabíjat ap. ${ }^{\prime 9}$, ku ktorému mohlo byt dodatočne utvorené i variantné (s)kántrit. Nedostatkom takejto konštrukcie je nepochybne jej celková hypotetickost', resp. nedoloženost jednotlivých článkov predpokladaného lexikálneho retazca.

4. V kontexte úvah o etymológii slk. kántrit však možno upozornit na formálnu blízkost” - konkrétne na slovníkové či „abecedné“ susedstvo ${ }^{10}$ - tohto slovesa a substantíva kántry pomn. '(v rímskokatolíckej cirkvi) trojdňový čas pôstu, modlitieb a pokánia v štyroch ročných obdobiach' (SSSJ II 524), ktorého najstarší písomný doklad pochádza z 18. stor.: czech každe kantri mssy da služity (Šaštín 1764; HSSJ II 23 s. v. kánter). Z hladiska pôvodu ide o plurálový tvar substantíva, ktorého forma sa v HSSJ štandardizuje ako kánter (s variantom kántor) a ktoré je v zmienenom význame ${ }^{11}$ doložené už v rukopisnej pamiatke Cantus et orationes (17. stor.): mame w czas cantru skromne ziwy bity.

Konečným etymologickým východiskom výrazu je lat. quattuor (tempora), t. j. 'štyri (obdobia)' (porov. už Matzenauer 1870: 193; Machek 1957: 191) ${ }^{12}$; formu

8 Išlo by o desubstantívne sloveso dnešného konjugačného typu robit, robím (z diachrónneho hladiska IV. slovesná trieda) so slovotvorným významom „byt tým alebo správat sa tak ako to, čo sa pomenúva základným substantívom“ (MSJ 456). - O slovanských desubstantívnych slovesách na ${ }^{*}$-iti porov. i Sławski (2011: 27).

9 O starých slovanských imperfektívach, resp. iteratívach na *-ati (s možným predľžením koreňového vokálu) porov. Sławski (2011: 15); k fungovaniu príslušného morfonologického modelu v prípade zjavne mladších slovesných formácií porov. i staršie slk. dokánčat' 'dokončovat" ako imperfektívum k dokončit' (HSSJ I $280 \mathrm{~s}$. v. dokončit).

10 Plne súhlasíme s názorom, podla ktorého „для серьезной этимологии нужно не ,алфавитное с соседство, от этимолога требуется широкий горизонт и умение сквозь внешнее подобие увидеть подлинную природу“" (Trubačov 2003: 243); požadovaná schopnost’ etymológa je však nepochybne dôležitá aj pre adekvátnu interpretáciu vzájomného vzt̉ahu výrazov nachádzajúcich sa práve v špecifickom „abecednom“ susedstve.

11 Podla údajov HSSJ mal uvedený výraz v staršej slovenčine aj významy štvrtročné obdobie, štvrtrok' a 'štvrtročne odvádzaný poddanský poplatok', v obidvoch prípadoch doložené už od 17. stor. - Zo slovenských nárečí je substantívum kántry známe v troch významoch (porov. SSN I 745): 1. 'pôstne dni predpísané cirkvou' (s celoslovenským rozšírením), 2. 'druh cirkevného poplatku' (doložené v gemerských nárečiach) a 3. 'stav, ked' niekto nemôže jest', pit' (napr. od hnevu)' (žartovné: No čo tỉ zaz je? Čo máš, kántri?! - Chocholná, okres Trenčín; Pala tuším kolera bere, zaz má kantri - Bzince pod Javorinou, okres Nové Mesto nad Váhom).

12 Rovnaké etymologické východisko má aj chorv. kvätre 'post što biva četiri puta na godinu' (Skok ERHJ II 252), sln. kvatre, kvátri 'id.' (Bezlaj II 116), ako aj pol. dial. kantopory 'suchedni' (SGPK II 303) či nem. Quatember (< quatertember) 'die nach alter päpstlicher anordnung zur weihe der priester bestimmte woche (am anfange jedes kirchlichen vierteljahrs), in welcher nebst 
slovenského výrazu mohlo ovplyvnit mad'. kántor-böjt 'kántrový pôst', v staršom jazyku i kántor 'štvrtročné obdobie' (doložené od r. 1508), prevzaté z rovnakého latinského zdroja (porov. MNyTESz II 351 s. v. kántorböjt; EWUng I 683 s. v. kántorböjt; Rocchi I 139 s. v. kánter) ${ }^{13}$.

Uvažujúc o možnosti etymologickej súvislosti výrazov kántrit a kántry (resp. staršie kántor, kánter), dospievame k záveru, že kántrit môže byt’ odvodenina od kántry, zaraditelná medzi desubstantívne slovesá dnešného konjugačného typu robit” „ktorými sa vyjadrujú deje vyplývajúce z podstaty veci pomenovanej základným substantívom“ (MSJ 457) - východiskový význam slovesa by v takom prípade bolo možné rekonštruovat azda ako *`zachovávat pôst predpísaný počas kántrových dní'.

Na základe sémantiky 'zachovávat' (kántrový) pôst' mohol vzniknút aj význam 'hladovat" - k príslušnému sémantickému posunu porov. i slk. postit' sa 'zachovávat' pôst, zdržovat' sa jedál, nejest'; hladovat' (SSJ III 326), vypostit' sa 'pôstom al[ebo] nedostatkom jedla stat sa hladným, vyhladnút', vylačniet' (SSJ V 272), čes. vypostiti 'postem, nedostatkem jídla učiniti lačným, vyhladoviti někoho', vypostiti se 'postem, nedostatkem jídla se státi hladovým' (PSJČ VII 325), pol.' wyposzczony 'taki, który długo pościł i jest wygłodzony' (SJP online s. v.) a i.

Sémantika 'zachovávat pôst, postit' sa', resp. blízka sémantika 'hladovat' - t. j. $\mathrm{v}$ obidvoch prípadoch 'neprijímat' potravu (v dostatočnom, resp. potrebnom

dem freitag und samstag auch der mittwoch strenggebotener fasttag war; sodann diese vierteljährliche fastenzeit, im bürgerlichen und geschäftlichen leben ein vierteljahr überhaupt, ein quartal' (DWB online s. v. Quatember); podla nemčiny asi aj čes. kvatembr 'půst čtvera suchých dnư' (PSJČ II 472).

13 Lat. quattuor (tempora) bolo prevzaté do madarčiny v podobe kántor pravdepodobne v dôsledku zblíženia s etymologicky nesúvisiacim mad'. kántor 'cirkevný spevák' (doložené od r. 1314 - porov. MNyTESz II 351 s. v. kántor; EWUng I 683 s. v. kántor), ktorého východiskom je lat. cantor ako nomen agentis od lat. canere 'spievat'; odtial' i slk. kantor, vo význame 'kantor a organista v kostole, vedúci kostolného zboru, kt[orý] často pôsobil aj ako učitel" doložené od r. 1586 (porov. HSSJ II 23; k dalším významom pozri SSSJ II 523). - Výraz kántore pl. 'postovi kvatre’ nachádzame aj v slovníku J. Mikalju (Blago jezika slovinskoga..., 1649): „Mikalja dürfte das Wort während seines mehrjährigen Aufenthaltes in Südungarn (Temesvár) gehört haben“ (Hadrovics 1985: 291 s. v. kantore). - HSSJ štandardizuje formu príslušného heslového výrazu v podobe kánter (porov. vyššie), z etymologických príčin by tu však zrejme bola vhodnejšia štandardizácia kántor. Na základe foriem kántry pl., kántrový možno predpokladat, že uvedené substantívum malo skloňovanie kántor - gen. sg. kántral-u, dat. sg. kántru ap. (okrem už citovaného dokladu mame $w$ czas cantru skromne ziwy bity porov. i $w$ kantru swatogirskem, swatoganskem, swatomichalskem, wianocžnem [vo význame š̌tvrtročné obdobie, štvrtrok'], Orava 1618; HSSJ loco cit.), t. j. s alternáciou $o / \varnothing$, napodobňujúcou stav vo výrazoch s príslušnými reflexmi jerových vokálov v silnej, resp. slabej pozícii. Forma kánter mohla vzniknút pod vplyvom prípadov typu dial. veter, brater, kmoter, loter (s vkladným e) - gen. sg. vetra, bratra, kmotra, lotra ap., napodobnuujúcich výrazy s jerovými striednicami e/Ø (porov. Stanislav 1967: 396 n.). 
množstve ap.)' - mohla takisto poslúžit ako základ pre vznik významu 'zbavovat' síl, oslabovat', vyčerpávat ap.'; porov. i vyššie citované čes. vypostiti v kontextoch typu nasyt české duše, vypostěné Vídní 'zbavené sil' (PSJČ loco cit.), pol. wypościć się vo význame 'wycieńczyć się, wynędzić się' (SW VII 980), srb.-chorv. ispòstiti $s e$ 'svršiti post; istrošiti se postom', ispošten 'istrošen postom (o tijelu)' (RJA III 941), rus. испости́ться, испа́щиваться 'истомляться постомъ, изнуряться воздержаньемъ отъ пищи' (Dal' II 132), sthnem. irfastên 'sich durch übermäßiges Fasten erschöpfen, schwächen, conficere' (EWAhd III 85), nem. sich abfasten 'jejunio macerari, durch langes fasten entkräften' (DWB online s. v. abfasten), strfr. adjeuner 'affaiblir par des jeûnes (le corps)' (FEW online s. v. jējūnare) a i.

Takýto sémantický posun mohol nastat aj v prípade slovesa kántrit'. Znamenalo by to, že na základe predpokladaného východiskového * kántrit 'zachovávat' pôst predpísaný počas kántrových dní' (nezvratné sloveso ${ }^{14}$ ) vzniklo zvratné kántrit'sa 'vyčerpávat' seba samého (kántrovým) pôstom; ničit' sa ${ }^{15}$, ku ktorému bol dodatočne utvorený nezvratný tranzitívny pendant kántrit' (niekoho/niečo) s významami, aké podla nášho názoru $\mathrm{v}$ značnej miere reflektujú sémantiku nezvratného slovesa ničit' '1. spôsobovat' velkú škodu, skazu, silne poškodzovat', narúšat' fungovanie niečoho al[ebo] privádzat' do neupotrebitelného stavu, kazit', znehodnocovat niečo, devastovat; 2. zbavovat niekoho duševných al[ebo] telesných síl, oslabovat', vyčerpávat', trápit', sužovat; 3. spôsobovat zánik, koniec existencie niekoho, niečoho, (fyzicky) likvidovat; 4. rušivo zasahovat do niečoho, nepriaznivo pôsobit na niečo, kazit', narúšat" (SSSJ III 1003) - porov. možné paralelné použitie typu kántrit'/ničit' myši, obyvatelov kántria/ničia choroby, kántrit'/ničit' životné prostredie, kántri/ničí ho neistota ap. ${ }^{16}$

$14 \mathrm{~K}$ predpokladanej nereflexívnosti porov. slk. postit ako regionálny variant („kraj.“, t. j. krajové slovo) reflexíva postit' sa 'zachovávat' pôst' (SSJ III 326 s. v. postit' sa).

15 Vo význame '2. spôsobovat' si velkú ujmu, duševne al[ebo] telesne sa oslabovat', vyčerpávat', trápit’ sa, sužovat’ sa’ (SSSJ III 1003).

16 V kontexte úvah o sémantike slovesa kántrit si nepochybne zaslúži pozornost jeho prefixálny derivát skántrit’ vo význame 'pozberat' (obilie) z pola' (porov. Palkowitsch II 2827: „Zkántrjm... fklidjm 2)“; v nadväznosti na neho i Kott online s. v.: „Zkántriti = skliditi [zboží]“, ako aj Kálal 1923: 607 s. v. skántrit', význam '1. zkliditi z pole’, s odvolaním sa na J. Palkoviča a J. Kollára). Vznik takéhoto významu možno azda objasnit napodobnením sémantiky slovesa kosit’, ktoré má okrem primárneho „polnohospodárskeho“ významu (kosit trávu, jačmeň, lúku ap.) aj sekundárny význam typu 'hubit', ničit', vlastný slovesu kántrit' - porov. smrt', choroba kosí (SSJ I 751 s. v. kosit: „o hromadnom umieraní ludí"), gul'ky kosia 'hromadne usmrcujú' (loco cit.), smrt'zubatá kosila 'ludia umierali vo vel'kom množstve' (SSSJ II 754 s. v. kosit'); porov. už doklad basiliskus swim gedowitim popatrenim wsecko kosi a morduge 'usmrcuje' (rukopisná pamiatka Sermones Jasov 1777; HSSJ II 111 s. v. kosit'). Takisto azda nemožno celkom vylúčit, že význam 'hubit', ničit" sa v slovese kosit' (pôvodne 'narábat' kosou' ako denominatívum od kosa; zrejme už psl. *kositi - ESSJa

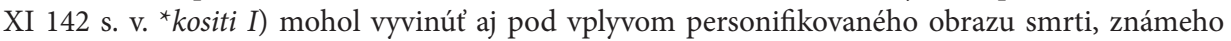
v slovenskej ludovej kultúre: „Najmladšou a najrozšírenejšou predstavou Smrti je kostlivec s kosou, 
5. Z uvedeného vyplýva, že v prípade slk. kántrit ide zrejme o výraz, ktorý vznikol až v rámci interného slovenského jazykového vývinu; ide teda o slovenskú lexikálnu inováciu, pre ktorú sa nám zatial nepodarilo nájst paralely v iných slovanských jazykoch. Genetické usúvztažňovanie slovenského výrazu s pol. dial. kętrzyć, kętrać považujeme za málo pravdepodobné; prezentovaná etymologická interpretácia môže zároveň svedčit v prospech predpokladu o slovenskej proveniencii pol. dial. skantrzyć.

\section{Bibliografia}

Bernolák Anton, 1825-1827, Slowár Slowenskí Češko-Latinsko-Ňemecko-Uherskí seu Lexicon Slavicum Bohemico-Latino-Germanico-Ungaricum, vol. I-VI, Budae.

Bezlaj France, 1977-2007, Etimološki slovar slovenskega jezika, t. I-V, Ljubljana.

Chorváthová Lubica, Smrt. In: Centrum pre tradičnú ludovú kultúru - elektronická encyklopédia, online: https://www.ludovakultura.sk/polozka-encyklopedie/smrt/ [citované 21.10.2018].

Dal Vladimir, 1903-1909, Tolkovyj slovarb živogo velikorusskago jazyka, t. I-IV (3-je, ispravlennoje i značitelno dopolnennoje izd.), S.-Peterburgъ-Moskva.

Duden online - Wörterbuch Duden online, online: https://www.duden.de/woerterbuch [citované 21.10.2018].

často na koni. Sprostredkovali ju z krestanského umenia stredoveké nástenné mal'by a kníhtlač“ (Chorváthová online). - Nie je jasné, či k derivátom od kántrit patrí aj dial. kántrovnica 'vyšitá stužka, ktorú si dievky dávali pod hlavnicu, aby vo sne videli svojho budúceho manžela' (SSN I 745: Rybany, okres Bánovce nad Bebravou); v nadväznosti na sémantiku 'zachovávat' (kántrový) pôst', predpokladanú pre sloveso kántrit ako možné slovotvorné východisko substantíva kántrovnica, by sa tu azda dalo uvažovat’ o situácii rituálneho využitia pôstu: „Pôst... sa prijímal aj za... získanie dobrého muža. Býval súčastou magických praktík, najmä pri veštení a čarovaní (Feglová online). Zdá sa však, že uvedené slovo možno usúvztažnit aj so slk. dial. kantrllík 'farebnej stužke podobná čipka na výrobu ludového odevu' (Kantrllíki boli šelijakej farbi - Návojovce, okres Topolčany; SSN loco cit., s. v. kantrdlík), ktorého východiskom je podla nášho názoru nem. dial. ${ }^{\star} K a n-$ terl ako sufixálna odvodenina (k sufixu porov. bavor.-rak. nem. Sack-erl 'Beutel, Tüte', rak. nem. Fleck-erl 'kleiner Fleck', rak. nem. Weib-erl hrub. 'Frau' ap.; Duden online s. vv.) od nem. Kante '1. hrot, špic, okraj; 2. ozdobný okraj so zubatými čipkami (von zacken oder 'spitzen' als schmuck... franz[ösisch] dentelles...)' (DWB online s. v. Kante). Predpokladané nem. dial. * Kanterl 'čipka’ sa stalo východiskom nielen pre slk. dial. kantrllík ako označenie čipky (porov. vyššie; rekonštrukcia formy príslušného heslového výrazu v SSN v podobe kantrdlik nie je adekvátna, kedže zdvojené $l l$ tu nie je výsledkom asimilácie typu jedla > jella, padla > palla ap., známej zo západoslovenských nárečí, Stanislav 1967: 358-359), ale pravdepodobne aj pre nedoložené *kánter (so zjednodušením

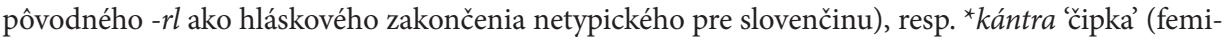
nínum zakončené na - $a$ analogicky podla čipka): od neho mohlo byt dalej odvodené adjektívum *kántrový, použité v spojení typu *kántrová stužka 'podobná čipke', ktoré sa stalo základom pre vznik odvodeniny kántrovnica, označujúcej vyšitú stužku používanú pri špecifickej príležitosti (porov. vyššie). 
DWB online - Deutsches Wörterbuch von Jacob Grimm und Wilhelm Grimm auf CD-ROM und im Internet, online: http://dwb.uni-trier.de/de/ [citované 21.09.2018]. ESSJa - Etimologičeskij slovar slavianskich jazykov. Praslavianskij lexičeskij fond, Moskva 1974-.

EWAhd - Etymologisches Wörterbuch des Althochdeutschen, Göttingen 1988-.

EWUng - Etymologisches Wörterbuch des Ungarischen, Bd. I-III, Budapest 1992-1997. Feglová Viera, Pôst, [in:] Centrum pre tradičnú ludovú kultúru - elektronická encyklopédia, online: https://www.ludovakultura.sk/polozka-encyklopedie/post/ [citované 21.09.2018].

FEW online - Französisches etymologisches Wörterbuch de Walther von Wartburg, online: https://apps.atilf.fr/lecteurFEW/index.php/site/rechercheAvancee [citované 21.09.2018].

Hadrovics László, 1985, Ungarische Elemente im Serbokroatischen, Köln-Wien.

HSSJ - Historický slovník slovenského jazyka, zv. I-VII, Bratislava 1991-2008.

Kálal Miroslav, 1923, Slovenský slovník z literatúry aj nárečí (Slovensko-český differenciálny), Banská Bystrica.

Kott online - Česko-německý slovník Fr. Št. Kotta, online: http://kott.ujc.cas.cz/ [citované 21.09.2018].

KSSJ - Krátky slovník slovenského jazyka (4., doplnené a upravené vyd.), Bratislava 2003.

LKEŽDB - Lietuvių kalbos etimologinio žodyno duomenų bazė, online: http://etimologija.baltnexus.lt/ [citované 21.09.2018].

Machek Václav, 1957, Etymologický slovník jazyka českého a slovenského, Praha.

Machek Václav, 1968, Etymologický slovník jazyka českého, Praha.

Matzenauer Antonín, 1870, Cizí slova ve slovanských řečech, Brno.

MNyTESz - A magyar nyelv történeti-etimológiai szótára, köt. I-IV, Budapest 1967-1984. MSJ - Morfológia slovenského jazyka, Bratislava 1966.

Palkowitsch Georg, 1820-1821, Böhmisch-deutsch-lateinisches Wörterbuch, mit Beyfügung der den Slowaken und Mähren eigenen Ausdrücke..., Bd. I-II, PragPreßburg.

PSJČ - Příruční slovník jazyka českého, sv. I-IX, Praha 1935-1957.

RJA - Rječnik hrvatskoga ili srpskoga jezika, t. I-XXIII, Zagreb 1880-1976.

Rocchi Luciano, 1999-2010, Hungarian Loanwords in the Slovak Language, vol. I-III, Trieste.

SEJP - Franciszek Sławski, Słownik etymologiczny języka polskiego, t. I-V [A-Ł], Kraków 1952-1982.

SEK - Wiesław Boryś, Hanna Popowska-Taborska, Słownik etymologiczny kaszubszczyzny, t. I-VI, Warszawa 1994-2010.

SGPK - Jan Karłowicz, Słownik gwar polskich, t. I-VI, Kraków 1900-1911.

SJP online - Słownik języka polskiego, online: https://sjp.pwn.pl/ [citované 21.09.2018]. Skok Petar, 1971-1974, Etimologijski rječnik hrvatskoga ili srpskoga jezika, knj. 1-4, Zagreb.

Sławski Franciszek, 2011, Słowotwórstwo, słownictwo i etymologia słowiańska, Kraków. SSJ - Slovník slovenského jazyka, sv. I-VI, Bratislava 1959-1968.

SSN - Slovník slovenských nárečí, Bratislava 1994-. 
SSSJ - Slovník súčasného slovenského jazyka, Bratislava 2006-.

Stanislav Ján, 1967, Dejiny slovenského jazyka. I. Úvod a hláskoslovie (3., doplnené vyd.), Bratislava.

SW - Słownik języka polskiego, red. Jan Karłowicz, Adam Antoni Kryński, Władysław Niedźwiedzki, t. I-VIII, Warszawa 1900-1927.

Trubačov, Oleg Nikolajevič, 2003, Etnogenez i kultura drevnejšich slavian. Lingvističeskije issledovanija (izd. 2-e, dopolnennoje), Moskva.

Zlatý fond denníka SME, online: https://zlatyfond.sme.sk/ [citované 21.09.2018].

\section{Streszczenie}

Artykuł jest poświęcony etymologii słowackiego czasownika kántrit'zabijać; niszczyć; spowodować cierpienie psychiczne', zestawianego (V. Machek, F. Sławski) z polskim dial. kętrzyć 'cudzołożyć', kętrać 'sprośnie, wszetecznie czynić'. Zdaniem autora wyraz słowacki jest derywatem od słowackiego kántry plt '(w tradycji Kościoła rzymskokatolickiego) suche dni, dni kwartalne’ < łac. quattuor (tempora); kántrit mogło być pierwotnie verbum intransitivum ze znaczeniem *'zachowywać post suchedniowy' - stąd chyba reflexivum kántrit' sa 'umartwiać się (postem suchedniowym)' (> 'tracić siły itd.; niszczyć się’) i, w końcu, transitivum kántrit 'niszczyć, zabijać itd.'. 